\title{
The impact of ethnicity and gender on agreement of severe allergy history between inpatient and outpatient electronic medical records
}

\author{
Kurt REINHART, Teresa CORBO, Edward EWEN, C. Michael WHITE. \\ Received (first version): 10-Jun-2008 Accepted: 24-Oct-2008
}

\begin{abstract}
${ }^{*}$
Objective: To evaluate the rate of allergy documentation during inpatient admissions and determine if discrepancies exist between ethnicities and English proficiency, genders, and by medication classes.

Methods: Patients at an outpatient clinic with severe medication allergies documented in their electronic medical record were identified. Inpatient hospital admissions following the date this allergy was documented were reviewed and the presence or absence of this documentation in the inpatient electronic medical record was noted. An overall rate of successful documentation of allergies was calculated by dividing the number of admissions where the allergy was entered into by the total number of admissions where the opportunity to enter the allergy existed. Each patients ethnicity, gender, and the class of medication to which they were allergic to, was also recorded to determine if difference exist within each demographic. Results: Overall, allergy information was successfully entered in $84.6 \%$ of 246 hospital admissions. This rate was significantly lower (37.5\%) among patients whose ethnicity groups, on average, have lower rates of English fluency. There was no significant difference between genders. Allergies to cephalosporins were less likely to be entered (44.4\%).

Conclusion: Patients who are not proficient in speaking English may be at an increased risk of experiencing an adverse drug reaction as their severe allergies are less likely to be documented during a hospital admission.
\end{abstract}

Keywords: Drug Hypersensitivity. Medical Records Systems, Computerized. Healthcare Disparities. United States.
*Kurt REINHART. Pharm.D. Department of Pharmacy, Christiana Care Health System, Newark, DE and Department of Pharmacy, Hartford Hospital, Hartford, CT (United States).

Teresa CORBO. Pharm.D. Department of Pharmacy, Christiana Care Health System, Newark, DE (United States).

Edward EWEN. MD. Department of Medicine. Christiana Care Health System, Newark, DE (United States). C. Michael WHITE. Pharm.D., FCCP, FCP, BCPS Department of Pharmacy, Hartford Hospital, Hartford, CT (United States).

\author{
IMPACTO DE RAZA Y GÉNERO EN LA \\ CONCORDANCIA DEL HISTORIAL DE \\ ALERGIAS ENTRE LAS HISTORIAS \\ CLÍNICAS ELECTRÓNICAS \\ HOSPITALARIAS Y AMBULATORIAS
}

\section{RESUMEN}

Objetivo: Evaluar la tasa de documentación de alergias durante el ingreso hospitalario y determinar si existen discrepancias entre razas y dominio del inglés, géneros, y grupos terapéuticos.

Métodos: Se identificó a pacientes en una clínica ambulatoria con alergias graves a medicamentos documentadas en su historial electrónico. Se revisaron los ingresos hospitalarios posteriores a la fecha de la documentación de la alergia y se registró la presencia o ausencia de esta documentación en la historia electrónica hospitalaria. La tasa total de documentación satisfactoria se calculó dividiendo el número de ingresos en los que se había registrado la alergia entre el número total de ingresos en los que existía la oportunidad de que existiese la alergia. También se registró la raza, género y grupo terapéutico de los medicamentos a los que era alérgico cada paciente, para determinar si existían diferencias entre demografías.

Resultados: En general, la información de alergias se registró correctamente en el 94,6\% de los 246 ingresos hospitalarios. Esta tasa fue significativamente menor $(37,5 \%)$ en pacientes cuyos grupos étnicos, en general, tenían menor dominio del inglés. No hubo diferencias significativas entre géneros. Las alergias a cefalosporinas fueron las menos frecuentes de ser registradas $(44,4 \%)$.

Conclusión: Los pacientes que no tienen dominio del inglés pueden tener un mayor riesgo de experimentar una reacción adversa, ya que sus alergias graves son menos probablemente documentadas durante el ingreso hospitalario.

Palabras clave: Hipersensibilidad a medicamentos. Sistemas de historiales médicos informatizados. Disparidades sanitarias. Estados Unidos.

\section{INTRODUCTION}

Medical errors are an important cause of morbidity and mortality in hospitalized patients. Eliciting patient allergies is a vital piece of information 
needed for safe inpatient prescribing of medications. This information is dependent upon either the communication between patient (or the patient's representative) with a healthcare provider, or the accession of previous records in which this communication occurred. There are more than 21 million people in the US who speak English less than "very well" and over 3 million who do not speak any. ${ }^{1}$ Patients for whom English is not their primary language or patients who are intimidated by the healthcare system due to their ethnicity or gender may not provide complete allergy data. A survey of healthcare quality showed that $43 \%$ of Hispanics with English as a second language had one or more problem(s) with communication with their doctor at their most recent medical visit. ${ }^{2}$ For healthcare providers treating hospitalized patients, the ability to access outpatient databases could be a way to more accurately elucidate patient allergies. However, the extent to which drug allergies are not elucidated and whether ethnicity or gender plays a role is not known.

We sought to evaluate the ability of health providers in a hospital to elicit all of the severe allergies previously determined in the outpatient medical record based on ethnicity or gender.

\section{METHODS}

This drug use evaluation was approved by the Institutional Review Board and was conducted at Christiana Hospital (referred to as the healthcare system) in Newark, Delaware. Patients with a severe allergy documented on the healthcare system's outpatient electronic medical record (EMR) (Centricity, GE Healthcare, UK) who subsequently were admitted at least one time to the healthcare system for inpatient care were eligible for inclusion. Severe allergy was defined as allergies of anaphylaxis or angioedema, allergies identified as a respiratory or shock reaction, and allergies with the word "severe" entered as free-text under the description. Patients were excluded if their drug allergy was not to one of the following medications: angiotensin converting enzyme inhibitors (ACEls), angiotensin receptor blockers (ARBs), aspirin, cephalosporins, penicillins, or sulfonamides. This was done to limit the scope of the project and to exclude non-drug allergies. Patients were also excluded if their prior inpatient admission had documented the allergy since the inpatient admission record is available for all subsequent hospitalizations.

The presence of any severe allergies in a patient's inpatient hospital EMR (Powerchart, Cerner Corporation, Kansas City, MO) for any subsequent admissions were compared to the severe allergies elicited in the outpatient EMR. Allergies could have been entered into the inpatient EMR up until the time of inpatient discharge to be considered documented. If both databases had documented the same allergy, a designation of "allergy identified" was applied. If the outpatient database identified a severe allergy not identified in the inpatient database, a designation of "allergy missed" was given. Data collection took place in November, 2006.

The number of applicable inpatient visits where severe allergies were identified was divided by the total population with identified severe allergies in the outpatient record to yield the percentage of agreement between the two medical records. The percentage of Caucasians with severe allergies identified were compared first with all minority groups, then minority groups with a likelihood of having language barriers, and finally with African Americans alone using chi square analysis. The percentage of males with identified severe allergies was compared to females using chi square analysis. The ability to identify severe allergies with different drug classes was also compared using $2 \times 5$ chi square analysis with individual differences probed by post-hoc $2 \times 2$ chi square analysis if indicated.

\section{RESULTS}

In our study, 240 patient profiles constituting 656 hospital admissions were reviewed by investigators. Demographic information is given in Table 1. Of the 656 hospital admissions reviewed, 410 had prespecified exclusion criteria leaving 246 admissions meeting our study criteria. Overall, the inpatient healthcare providers identified the severe allergy documented in the outpatient medical record $84.6 \%$ of the time. Caucasians had a trend towards being more likely to have inpatient identification of severe allergies than all minority groups combined $(p=0.103)$. However, when the minority population was fractionated into individual groups, the effect was not consistently seen across groups. When Latinos and Asians (minority groups where more than $35 \%$ of people do not have very good English proficiency ${ }^{3,4}$ ) were compared to Caucasians, Caucasians were 1.3 fold more likely to have severe allergies identified and recorded in the medical record $(p<0.001)$. However, African Americans had virtually the same percentage of successful allergy identification as Caucasians $(p=0.879)$. The ethnicity comparisons are given in Table 2. No differences in the ability to identify severe allergies as inpatients were noted between males and females $(88.9 \%$ vs $84.0 \%, p=0.705)$.

\begin{tabular}{|l|l|}
\hline \multicolumn{2}{|l|}{ Table 1: Patient Demographics } \\
\hline Ethnicity & $2(0.8)$ \\
Asian & $81(32.9)$ \\
Black & $14(5.7)$ \\
Latino & $149(60.6)$ \\
Caucasian & \\
Medication Class of Severe & \\
Allergy & $24(9.8)$ \\
ACEl/ARB & $31(12.6)$ \\
Aspirin & $18(7.3)$ \\
Cephalosporins & $131(53.3)$ \\
Penicillins & $42(17.1)$ \\
Sulfonamide & converting enzyme \\
\hline ACEl/ARB: Angiotensin cong blockers \\
inhibitors/angiotensin receptor block
\end{tabular}

Table 3 summarized the rate of allergy identification by medication class. There was a statistically significant difference between the groups $(p<0.001)$ using $2 \times 5$ chi square analysis. When post-hoc $2 \times 2$ chi square analyses were performed, differences 
were noted for all medication classes compared to the cephalosporin class, with this group having a significantly lower rate of allergy identification. There were no significant differences between the other groups.

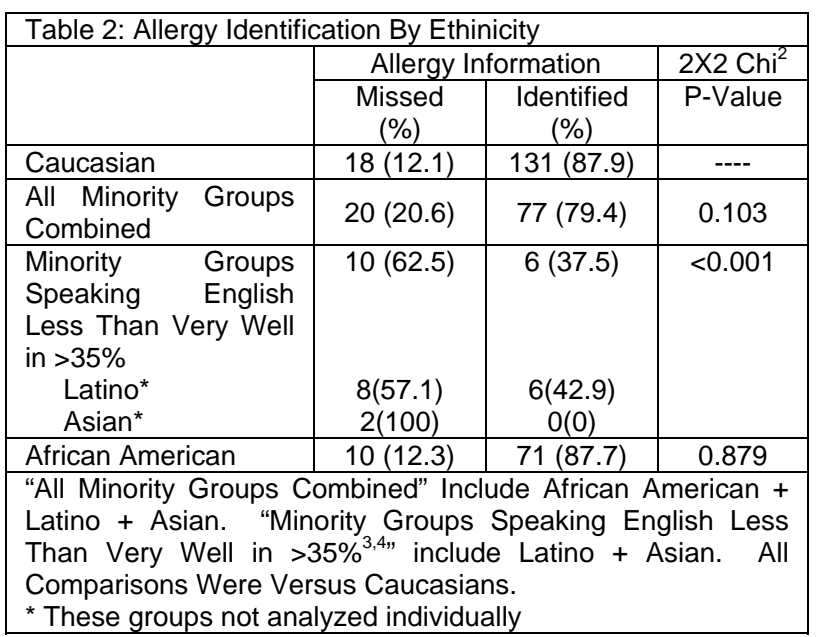

\begin{tabular}{l}
\hline $\begin{array}{l}\text { Table 3: Allergy Identification By Medication Class } \\
\text { (percentage) }\end{array}$ \\
\hline
\end{tabular}

\section{DISCUSSION}

The population of non-English speaking residents in the US is large and growing. Their ability to communicate with health professionals and interpret medical information given from health professionals may be less than that of the English-fluent patient. Although this study grouped patients by ethnicity without measure of English language fluency, census data demonstrates that the Asian and Latino populations are more likely to speak English as a second language when compared to Caucasians and African Americans. Roughly $79 \%$ of Asians report speaking a language other than English at home. When asked to rate fluency in the English language, $37 \%$ of Asians reported speaking English less than 'very well'. ${ }^{3}$ Similarly, $78.5 \%$ of Hispanics report speaking a language other than English at home. When asked to rate fluency in the English language, 40.6\% reported speaking English less than 'very well'. ${ }^{4}$ As a comparison, just $7 \%$ of African Americans reported speaking a language other than English at home. ${ }^{5}$

Patients who are not fluent in English may be at an increased risk of not having vital allergy information documented in their medical records during a medical encounter. With approximately 66 million encounters taking place annually between providers and patients with a language barrier, the potential for harm when allergy information in not documented is great. ${ }^{6}$ In our study, subjects of Asian and Latino ethnicity did not have the same level of allergy ascertainment as Caucasians when admitted into the hospital. The results of a previous study demonstrated Spanish speaking patients are far less likely to make comments to their physicians even when using an interpreter. ${ }^{7}$ This suggests that cultural differences or the insecurity stemming from not speaking the majority language in a culture is a disincentive for communicating with health professionals and this problem may not be solved with interpreters alone. A healthcare system with interfaced or integrated outpatient and inpatient medical records could provide additional mechanism to catch missing allergy information. The similar rates of successful documentation of allergy information between females and males upon admission to the hospital shows that gender does not appear to affect the communication between patient and healthcare professional.

This study was limited in that rather than comparing groups based upon their use of English proficiency, it was assumed, based on census statistics, 3,4 that the Asian and Latino populations studied would have a lower rate of English fluency compared to Caucasians and African Americans. This along with the low numbers of patients within these demographics may have increased the probability this discrepancy found is not accurate. The finding that cephalosporin allergies were less likely to be documented may support the argument for a language barrier as this medication class may be less known to the general population compared to aspirin and penicillin.

\section{CONCLUSIONS}

Patients with low English proficiency are less likely to have severe allergies documented during hospital admissions and therefore may be at an increased risk of experiencing an adverse drug reaction. Gender does not appear to influence the documentation of severe allergies. Ethnicity and gender aside, the overall rate of allergy documentation was less than desirable. An interface between outpatient and inpatient electronic medical records is one tool that may assist in improving severe allergy documentation.

\section{CONFLICT OF INTEREST}

The authors have no conflicts of interest, financial or otherwise, regarding this study. 


\section{References}

1. Language Use and English-Speaking Ability:2000. U.S. Census Bureau Web Site. Available at: http://www.census.gov/prod/2003pubs/c2kbr-29.pdf. Accessed September 19, 2007.

2. Diverse Communities, Common Concerns: Assessing Health Care Quality for Minority Americans. The Commonwealth Fund 2001 Health Care Quality Survey Web Site. Available at:

http://www.commonwealthfund.org/usr_doc/collins_commonconcerns_surveycharts.pdf?section=4056. Accessed September 19, 2007.

3. We the People: Asians in the United States. Census 2000 Special Reports, December 2004. US Census Bureau Web Site. Available at: http://www.census.gov/prod/2004pubs/censr-17.pdf. Accessed December 19, 2007.

4. We the People: Hispanics in the United States. Census 2000 Special Reports, December 2004. US Census Bureau Web Site. Available at: http://www.census.gov/prod/2004pubs/censr-18.pdf Accessed December 19, 2007.

5. New Population Profiles Released by Census Bureau:American Community Survey Data Iterated by Race, Hispanic origin, Ancestry and Age. US Census Bureau News, November 14, 2006. Available at: http://www.census.gov/PressRelease/www/releases/archives/american_community_survey_acs/007748.html. Accessed December 19, 2007.

6. American College of Physicians. Racial and Ethnic Disparities in Health care. A Position Paper of the American College of Physicians. Ann Intern Med 2004;141:226-32.Rivadeneyra R, 7. Elderkin-Thompson V, Silver RC, Waitzkin H. Patient Centeredness in Medical Encounters Requiring an Interpreter. Am J Med 2000;108:470-474. 